\title{
DUYURU
}

\section{Inceleme Yaziları}

"S.S.K. İmir Tepecik Hastanesi Dergisi" okuyucuların ilgisini çekerek aktüel ve ilginç konularda kaleme alınacak inceleme yazılarına açıktır. Yazısı bu bölümde yeralacak otörlere 1 yıllık abone ve ayrı baskı ücretsiz olarak gönderilecektir. Hazırlanacak incelemenin konu seçimi ve içerik altbaşlıkları ile ilgili yazışma için Editör "Doç. Dr. R. Kayar S.S.K. tepecik Hastanesi 1. Hrc. Kli. Şefi 35120 IZMIIR" ile temas edilmelidir.

Türkiye'de Yapıllmış Çalışmaların Toplu Değerlendirilmesi

Belirli bir konuda yerli literatürü inceleyip, araştıran ve yararlı sonuç ve çözümler öneren yazılara dergimizde "öncelikle" yer verilecektir. Bu tür çalışmalar arasında yapılacak seçimde "en başarillı çalışmaya" verilmek üzere bir ödül konması planlanmaktadır.

\section{Çalışmalarda Yerli Kaynak Oranı}

Dergimize müracaat eden çalışma sayısı her geçen gün sür'atle artmakta ve yılda 3 kez çıkarılan dergimizin şimdilik (ek sayı) ile 4'e, gelecekte de 6 sayı olarak çıkarılması düșünülmektedir.

Gelen çalışmalar arasında yayın sıra ve tercihinde "ÖNCELIK" kaynaklardaki yerli yayın sayısının fazla olduğu çalışmalara verilecektir.

\section{Mektuplar}

Yayınlanmış çalışmaları kritize eden veya katkı sağlayan yorum türü yazılara dergimizde kısıtsız yer ayrılmıștır. Dergimizde bilimsel centilmenlik prensiplerini korumak şartıyla HER ELEŞTIRI VE KATKI YAZISINA YER VERILECEKTIR.

\section{Yeni Kitap ve Periodik Yorumlari}

Yeni çıkan kitapları okuyucuya tanıtan, teknik özelliklerini aktaran, bilimsel içerik ve düzeyini yorumlayan yazllar beklenmektedir. Her tür tıp kitabı ve periodiği yeni basılmış olmak koşuluyla bu köşede duyurulacaktır.

\section{Bilimsel Toplant Duyurulari}

Ülkemizde yapılan Kongre, Simpozyum, Panel, Mezuniyet Sonrası Kurs gibi bilimsel faaliyetlere katılımları artırmak için dergimiz editörlüğüne toplantı tarihinden yeterli bir süre öncesinden bilgi vermek koşuluyla duyurular yayınlanabilmektedir.

Illgililerin dergimizin baskıya giriș tarihlerini (șimdilik 15 Ocak, 15 Mayıs, 15 Eylül) hesaba katmaları gerekmektedir.

Editör

Doç. Dr. R. Kayar 